Bartın Üniversitesi

Cesm-i Cihan:

Tarih Kültür ve Sanat Araștırmaları E - Dergisi

ISSN: 2149-5866 Cilt:4, Sayı:2, s. 72-82, Kıș 2017

BARTIN - TÜRKIYE

\author{
Bartın ve Yöresi \\ Tarih - Kültür Araştırmaları \\ Uygulama ve Araştırma \\ Merkezi
}

(BAYTAM)

\title{
ERMENİLERİN TARİHİ OLAYLARA YAKLAŞIMINDAKİ NESNELLİĞİN SORGULANMASI: “KAHRAMAN” ANDRANİK OZANYAN ÖRNEĞİ
}

\author{
Yrd. Doç. Dr. Melek SARI GÜVEN*
}

\begin{abstract}
Özet: Her milletin kendi tarih yazım geleneğini oluşturup sürdürmesi farklı koşullar içinde gerçekleşir. Tarihin dile geldiği coğrafya, dil, kültür ve olayların geçtiği zaman dilimi tarihi olayların gelişimini etkileyen unsurlardandır. Bu sebeple kahramanların işlevleri ve etkisini gösterdiği insan topluluğu her millet için farklı özellikler gösterir. Bir millet için yüzyıllarca şükran duyulan bir figür, başka millet ya da milletler için acımasız bir çete reisine dönüşebilir. Günümüzde, iletişimsizliğin sürdüğü Türkiye-Ermenistan ilişkilerinde durum tamamen aynı figürlere farklı işlevleri yüklemek şeklinde devam etmektedir. Türklerin "katliamcı bir çete reisi" olarak kabul ettiği Andranik Ozanyan Ermeniler için bir kahramandır. Bu durumda tarihte nesnellik kavramından söz etmek oldukça zorlaşır. Çünkü Ermeniler geçmişte kalan bir ismi tekrar kurgulayarak bir manipülasyon aracı haline getirmişlerdir. Bu çalışmada, Andranik Ozanyan örneği üzerinden gidilerek, tarihte Ermenilerin nesnelliğin dayandığı temel prensipleri yeniden inşa edişleri ve kahraman/kahramanlık olguları eleştirel tarih metodu yaklaşımıyla incelenecektir.
\end{abstract}

Anahtar Kelimeler: Tarih yazıcılığı, nesnellik, Andranik Ozanyan, kahraman, kahramanlık.

\section{ARMENIAN APPROACH TO HISTORICAL EVENTS QUERY OF OBJECTIVITY: EXAMPLE OF "HERO" ANDRANIK OZANIAN}

\begin{abstract}
Every nation has its own historiographical tradition in different circumstances. The geography, language, culture, and the time period in which the events are spoken are the factors affecting the development of historical events. For this reason, the heroes' functions and their impact on the human community show different characteristics for every nation. A figure who has been gratified for centuries for a nation can turn into a ruthless gang for other nations or nations. Nowadays, the situation in TurkeyArmenia relations, which is continuing with the lack of communication, continues to carry different functions to the same figures. Andranik Ozanyan, whom Turks regard as a "mass murderer", is a hero for Armenians. In this case, it is very difficult to talk about the concept of objectivity in history. Because the Armenians have reconstructed a past name and made it a tool of manipulation. In this study, going through the example of Andranik Ozanyan, the rebuilding of the basic principles which the Armenians have based on their object in history and their perspectives of heroes/heroism will be examined with the approach of the critical history method.
\end{abstract}

Keywords: Historical writing, objectivity, Andranik Ozanian, hero, heroism.

\section{GÍRIŞ}

1865 yılında doğmuş olan Andranik Ozanyan'ın yaşadığı dönem Ermenilerin bağımsızlık hareketlerine hız verdiği ve Osmanlı Devleti yönetiminden uzaklaşmak için faaliyetlerde bulunup teşkilatlandığı bir dönemdir. Bu faaliyetlerin organize edicileri Ermeniler için ulusal kahramanlar; bünyesinde yaşıyor oldukları Osmanlı Devleti için ise çete reisleri şeklinde resmedilebilir. Her döneme damgasını vuran lider ya da liderler veya kahraman ya da

\footnotetext{
* Bartın Üniversitesi, Edebiyat Fakültesi, Tarih Bölümü.
} 
kahramanlıklar olduğu için bu isimlerin doğru adlandırılmaları, yaşatılmaları ve hak ettikleri önemi almaları oldukça önemlidir. Bir ulusun varlığını kesintisiz devam ettirebilmesi için bu liderlerin benimsenmesi ve korunması önem taşır. Çünkü zamanla kahramanlaştırılan bu imgeler o milletin tarihinin kesintisiz yaşatılması için önemli figürler haline dönüşür. Kısaca söylemek gerekirse tarihte yaşatılan kahramanlar her millet için her zaman önemli figürler olmuştur. Ancak bir milletin kahramanı diğer milletin kahramanı değildir. Bu durumda tarih yazıcılığının kavramlarıyla hareket etmenin gerekliliği ortaya çıkmaktadır.

Objektif bilgi olasılığının yıkıldığı günümüz tarihçiliğinde tarihsel nesnelliği tanımlamak oldukça güçtür. Bir de bu tarihsel nesnelliğe bir milletin kahraman yaratma çabası eklenirse durum daha da karışık bir hal alır. Ancak bu durum nesnellikten vazgeçileceği anlamına da gelmez. Önemli olan, olayları sadece geçmişteki seyri ile değil de günümüze taşıyarak değerlendirmektir. Mark Bevir, rasyonel doğruluk, kapsamlılık, tutarlılık, ilerleme, verimlilik ve açıklık kriterlerine dayanarak nesnellik kriterinin üzerinde daha kolay konuşulabileceğini iddia etmiştir (Bevir 1994: 328.) Böylece nesnellik belirli bir geçmişe göre değil de karşlaştırma kriterlerine göre verilmiş olacaktır. Ayrıca, tarihi olayların incelenmesinin bu kriterler yardımıyla yapılması, olaylara ve kişilere yüklenecek duygusal ve yanlı anlatımları da engelleyecektir. Bu şekilde bir tanımlama, geçmişte yaşanmış olayların aydınlatılması ve kahraman konumuna yükseltilecek tarihi bireylerin daha objektif bir değerlendirmeye tabi tutulmasına yardımcı olacaktır. İskoç asıllı tarihçi, deneme ve hiciv yazarı Carlyle, kahraman ve kahramanlık tanımlamasının oldukça geniş ve büyük bir konu olduğunu dile getirmiştir. Carlyle, kahramanların dünya tarihine nasıl şekil verdiklerini; hangi fikirleri üretip yaydıklarını; ne yaptıklarını ve insanları nasıl etkilediklerini sorgulamıştır (Carlyle 1840: 1-5). Bu çalışmada Andranik Ozanyan örneği üzerinden gidilerek Ermenilerin, tarih yazımında nesnellik ve kendi kahramanlarını oluşturma konusundaki yaklaşımları üzerinde durulacaktır.

\section{Andranik Toros Ozanyan}

Andranik Ozanyan, 25 Şubat 1865 yılında Şebinkarahisar' da ${ }^{1}$ doğmuştur. Andranik adının anlamı Ermenice'de “ilk doğan” anlamına gelmektedir. Andranik bir yaşında iken annesini öldügünden ablası Nazeli tarafından büyütülmüștür. Bir süre babasının marangoz atölyesinde

\footnotetext{
${ }^{1}$ Şebinkarahisar, Şehzadeler Şehri olarak anılır. Karahisar-ı Şarki adıyla ve sancak olarak yönetilmiștir. Şebinkarahisar, 1473 Otlukbeli Savaşı ile Fatih Sultan Mehmet zamanında, Akkoyunlu Devleti'nden Osmanlı Devleti'ne geçmiştir. 1890 yılında Sivas vilayetine bağlı olan Şebinkarahisar Sancağına; Merkez kaza, Koyulhisar, Hamidiye, Suşehri, Alucra kazaları dahildir. Sancak merkezinde 4800 Sünni; 2500 Müslüman Alevi, 1700 Gregoryen Ermeni, 750 Protestan Ermeni ve 300 Katolik Ermeni ile 1650 Ortodoks Grek vardı.(Abdulhalim Durma, Evliyalar Şehri Giresun, Yenigün Matbaacılık San., Ankara, 2013, 80-97)
} 
çalışmıştır. 1875-1882 yılları arasında Muşeğyan Okulu'nda² okumuştur. 17 yaşında evlenmiş ve bir yll sonra oğlu doğduktan sonra eşi ölmüştür (UnujuidAğayan 1968: 40.; <ujluuluú Unluntunuluui <uunuqhununud/ Ermeni Sovyet Ansiklopedisi 1974: 392). Andranik Ozanyan'ın hayatına dair verilen yukarıdaki bilgilerden anlaşıldığı üzere Andranik, eğitimine 7 yıl devam etmiş sonrasında 1 yıl evli kalmış ve 18 yaşından itibaren siyasi faaliyetlerine başlamıştır.

\section{Andranik Ozanyan'ın Faaliyetleri}

Andranik Ozanyan, 19. yüzyılın sonlarından itibaren hem fikri hem de siyasi olarak faaliyetlerine başlamıştır. Bu konudaki bilgiler özellikle Ermeni kaynakları incelenerek ve Türkçe'ye aktarılarak verilecektir. Ermeniceden aktarılan bilgilerin nesnellikle ilgili sorgulanması gereken tarafları yazının akışına göre bazen metnin sonunda bazen de metnin çevirisiyle birlikte verilecektir. Böylece Ermeni tarihçilerin tarihi olayları aktarımındaki öznellik daha iyi ifade edilmiş olacaktır.

Andranik Ozanyan'ın faaliyetleri hakkında bilgi veren eserler incelendiğinde tarih yazıcılığında nesnellikle uyuşmayan ifadelerden bir örnek verecek olursak, Tzatur Ağayan'ın 1968 yılında Erivan'da Ermenistan Bilimler Akademisi ${ }^{3}$ tarafından yayımlanmış olan kitabına bakalım. Ağayan'ın, Komutan Andranik'in Faaliyetleri Hakkında isimli kitabında geçen “...Ermeni nüfusunu tehdit eden jandarma..." ifadesi oldukça iddialı ve öznel bir ifadedir. Burada, Andranik'in jandarmaya saldırması meșru kılınmaya çalışılmış ve buna sebep olarak da jandarmanın tutumu gösterilmiştir. Bu ifadenin devamı ve bu konudaki diğer bilgiler şu şekildedir: Andranik Ozanyan, 1882 yılında Ermeni nüfusunu tehdit eden jandarmaya saldırmaktan hapsedildi. İki yıl sonra arkadaşlarının yardımıyla hapishaneden kaçan Ozanyan, İmparatorluğun başkenti İstanbul'a yerlești. 1884-1886 yılları arasında burada marangoz olarak çalıştı (UnujứlAğayan 1968: 41-56). 1888 yılında Sivas'ta devrimci faaliyetlerine başladı (Snnglnı/Trotsku 1980: 247).

\footnotetext{
2 19. yüzyılda Şebinkarahisar'da Muşegyan ve Surp Pırgiçyan okulları bulunuyordu. 20.yüzyllın başında Muşeğyan Okulu'nda 58 kız öğrenci ve 84 erkek öğrenci,Pırgiçyan Okulu'nda ise 47 kız öğrenci ve 248 erkek öğrenci okumaktaydı.(Fatma Acun, TDV DIA, 393-395.)

${ }^{3}$ Ermeni Bilimler Akademisi, 25 Kasım 1943'te SSCB Bilimler Akademisi'nin Ermeni dalı olarak kuruldu. 1993 yllindan beri Ermenistan Cumhuriyeti Ulusal Bilimler Akademisi olarak hizmet vermektedir. Akademinin bütçesini devlet destekliyor olsa da çeşitli devlet kurumlarından ve yurtiçi-yurtdışı özel vakıflardan da destek alıyor. Akademi beş bölümden oluşuyor. Bu birimler, Matematik ve Teknik Bilimler; Fizik ve Astrofizik; Doğa bilimleri; Ermeni Araştırmaları ve Sosyal Bilimler; Kimya ve Yerküre Bilimleri ile 50 bilimsel kuruluş ve diğer kurumlardan oluşuyor. 3700 kişilik personeli içinde 87 akademisyen, 18 uzaktan katılımcı üye, 323 bilim adamı doktor ve 1006 bilim adamı adayı var.

http://culture.am/hy/directory/address/hujuunuiuh-qhunnıjnı\&uftiph-uqqujhi-ul/

[04.11.2017,20.41]
} 
Ozanyan, 1891 yılında Hınçak Partisinekatıldı. 1892 yılında, İstanbul Emniyet Müdürüne yapılan suikasta katıldığı için tutuklandı ancak kısa bir süre sonra cezaevinden yine kaçtı (〈upnıрjnı\&juiq/ Harutyunyan 1965: 109). Andranik Ozanyan, 1892 yllında iki yll önce kurulmuş olan Ermeni Devrimci Federasyonu'na ${ }^{5}$ katıldıysa da 1917 yılında bu federasyondan ayrılmıştır (Snnglnı/Trotsku 1980: 247-256). Ancak, Ozanyan'ın faaliyetleri 1892 yılından itibaren devam etmiştir. Onun giriştiği faaliyetlere verilebilecek örnek de Trotsku'nun eserinde geçen “...1894 ve 1896 yıllarında Muş ve Sasun'daki Ermeni köylerini Türk ve Kürt saldırısına karşı korudu."(Spnglnı/Trotsku 1980: 249) șeklindeki ifadedir. Bahsedilen dönem 19. yüzyılın sonları, olayın yaşandığı coğrafya ise Muş ve Sasun'un bulunduğu bölgedir. Bu bölgede yaşanan olayların bu şekildeki aktarımı Türklerin, Ermenilerin yaşadığı yerleri fethetmek için saldıran ve buradaki toprakları almak için mücadele eden savaşçllar şeklinde algılanmasına sebep olmaktadır. Türkler zaten o bölgede yaşayan yerli halktır. Oysaki Daşnabedyan'ın da ifade ettiği gibi, 19. yüzyılın sonları Ermeniler için, köylülerin silahlandırıldığı, Osmanlı Devleti'ne karşı teşkilatlanmanın ögütlenildiği bir dönemdir (Dasnabedian 1989: 67-70).

Andranik Ozanyan, 1897 yılında Ermeni Devrimci Federasyonu Taşnaktsutyun'un karargâhının olduğu Tiflis'e gitmiştir (Waller 1990: 441). Marmaryan'ın verdiği bilgilere göre; daha sonra Serob Vardanyan ${ }^{6}$ ile tanışmış ve Fedailer ${ }^{7}$ denilen ekibe katılmıştır. 1899 yılında Serob’un ölümü üzerine Van ve Sasun Ermeni Fedaileri'nin lideri olmuştur. 1901 yılında Muş, 1904 yılında Sasun'da savaşlarda8 ${ }^{8}$ bulunmuştur.1905 yılında Kafkasya'ya giden Andranik burada, Ermeni ulusal hareketinin önde gelen isimleriyle Osmanlı çetelerine karşı mücadele konuları tartışmıştır. Ardından Fransa, İsviçre, Belçika, İngiltere, Bulgaristan ve İran'ı da içine alan uzun bir seyahate çlkmış olan Andranik, Ermenileri ulusal kurtuluş mücadelesi ${ }^{9}$ ve silah

\footnotetext{
${ }_{4}^{4} 1887$ yılında Cenevre'de bir grup Ermeni öğrenci tarafından kurulan Ermeni siyasi partisidir. Hınçak kelimesi Ermenice çan anlamına gelir. Aynı isimli bir de dergi çıkarmışlardır. Üyelerinin büyük çoğunluğu Rusya Ermenileriydi. Büyük Ermenistan kurmak amacıyla silahlı eylemler ve isyanlar çıkararak

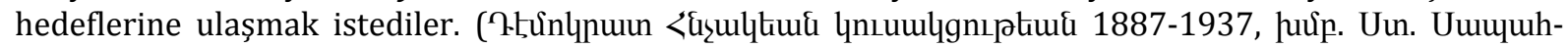

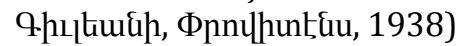

51890 yılında Tiflis'te kurulmuş olan Ermeni siyasi örgütüdür.

61864-1899 yılları arasında yaşamıștır. Ermeni Demokratik Liberal Parti üyesidir.

7 Tarihin farklı dönemlerinde çeşitli devrimci parti üyeleri, terör örgütleri ve terör örgütleri tarafından kullanılan anlayış anlamlarına gelmektedir. Buradaki anlamı, özgürlük için mücadele eden ve bu isimle bir

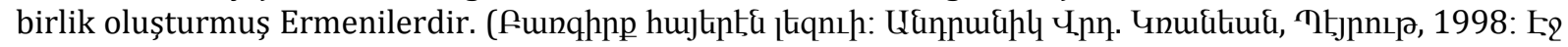
504:)

8 Bu örnekte de görüldüğü gibi; Ermeniler, bünyesinde yaşıyor oldukları Osmanlı Devleti'ne karşı giriştikleri ayaklanmaları ve başkaldırıları savaş olarak nitelemektedir. İlerleyen satırlarda da Van Savaşı, Muş Savaşı şeklindeki ifadeleri görmek mümkün.

${ }^{9}$ Ermenilerin, Doğu Anadolu'da bir Ermeni Devleti kurma fikridir. Ermeniler, 19. yüzyılın son çeyreğinden itibaren silahlı faaliyetlerde bulunmuşlar ve Osmanlı Devleti'nin savaşta bulunduğu dönemlerde önemli bir güvenlik sorunu teşkil etmişlerdir. Zaman zaman kendilerini Ermeni milliyetçisi veya Ermeni devrimcisi olarak isimlendirmişlerdir.
} 
edinme konularında bilgilendirmiştir. 1906 yılında Cenevre’ye giderek "Askeri Talimatlar"10 adlı kitabını yayınlamış; 1912-13 yılları arasında, Balkan Savaşları'na Bulgar ordusunda, Ermeni yardımcı birliklerinin komutanı olarak katılmıştır. Birinci Dünya Savaşı sırasında, Rus ordusunun Ermeni gönüllü birliklerinin başkanlığına getirilmiş, cesareti ve muhalif güçleri yenmek için kullandığı taktikler nedeniyle şöhret kazanmıştır. Van Savaşı sırasında şehri yeniden Osmanlı Devleti güçlerinden kurtarmak için yardım etmiştir. Ayrıca Mustafa Kemal'in kontrolü altındaki Osmanlı Devleti güçlerinden Bitlis şehrini ele geçiren tabur komutanıydı. Ermeni nüfusunun Osmanlı Devleti'nden kaçmasına ve Rusya'nın kontrolünde bir birim kurmasına yardımcı oldu. Bu bölge daha sonraki yıllarda Ermenistan Demokratik Cumhuriyeti oldu. Ermenistan Demokratik Cumhuriyeti kurulduktan sonra, Osmanlı Devleti ordusu ile savaşmak için gönüllü birliklerle birlikte örgütlendi ve savaştı. Andranik, Batum Antlaşması'nın ${ }^{11}$ imzalanması sırasında orduya karşı Osmanlı aleyhinde savaşta bulundu ve antlaşmanın belirttiği sınırları kabul etmedi (http://hyeforum.com/index.php?showtopic=18153); (Uunर्ưupưu 1920).

Hem Marmaryan tarafından aktarılan hem de Ermeniler tarafından servis edilen ve 2008 yılından beri aktif olan "hyeforum" adlı internet sitesinden aktarılan Andranik Ozanyan ile ilgili yazılanlar yukarıdaki paragrafta verilmiştir. Her gün binlerce kişinin ziyaret ettiği bu internet sitesinde verilen bilgilerde, Andranik Ozanyan'ın Ermenilerce, Türklere karşı Ermenilerin haklarını koruyan bir kahraman olarak tasvir edildiği görülmektedir. Yazının devamında “Osmanlı çeteleri ..." şeklinde geçen bir ifade vardır. Dönemin imparatorluklarından biri olan Osmanlı İmparatorluğu'nun askerleri için "çete" ifadesini kullanmak da nesnellikten uzak bir yaklaşımı işaret etmektedir. Ermeniler, düzenledikleri silahlı eylemleri direniş, özgürlük savaşı, halkın korunması için yapılan eylemler olarak tanımlarken karşı tarafı yani Osmanlı Devleti'ni katliam yapmakla suçlamışlardır. Osmanlı Devleti'ne karşı giriştikleri isyan hareketlerini savaş olarak nitelemişlerdir.“...Van Savaşı sırasında şehri yeniden Osmanlı Devleti güçlerinden kurtarmak için yardım etmiştir..." cümlesini inceleyecek olursak Van Savaşı ve Osmanlı Devleti Güçleri dikkat çekici iki ifade olarak karşımıza çıkar. Osmanlı Devleti'nin kendi vilayeti üzerinde kendi tebaası tarafından çıkarılan bir ayaklanmanın savaş olarak kabul edilmesi ve Osmanlı askerlerinden Osmanlı Devleti Güçleri şeklinde bahsedilmesi nesnellikten uzak ifadeler olarak yer almaktadır.

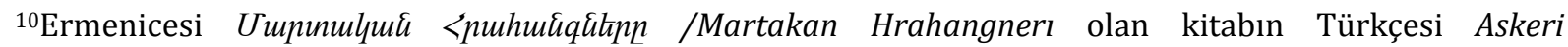
Talimatlar'dır. Bu kitapta askerlere maddeler halinde talimatlar vermektedir. Bu maddelerden birkaç örnek verelim: 1-Kesinlikle gizli olunuz, 2-Davanın gerektirdiği disipline tabi olunuz, 3-Egzersiz yaparak dinç ve temiz olunuz. gibi. (Uununulu氏 <nuhuiquitin, 1905)

${ }^{11} \mathrm{Bu}$ Antlaşmaya göre; Kars, Ardahan, Batum Osmanlı sınırlarında kalmıștır.
} 
Yüzyıllarca Osmanlı Devleti çatısı altında yaşamış olan Gayrimüslimlerden olan Ermeni Andranik Ozanyan'ın, Balkan Savaşları'na Bulgar ordusunda Ermeni yardımcı birliklerinin komutanı olarak katılması, Birinci Dünya Savaşı'na Rus ordusunun Ermeni gönüllü birliklerinin komutanı olarak katılması tarihsel objektifliğin sorgulandığı bir yazıda iki somut gösterge olarak karşımıza çıkmaktadır. Bu olaylar gösteriyor ki, Ermeniler için kahramanlık ifadesi olan eylemler tarihin nesnellik süzgecinden geçirildiğinde kahramanlık ifadesi ile eşleşmiyor. Ermeniler için kahraman yaratma süreci, nesnelliğin oluşma kriterlerinden olan rasyonel doğruluk ve tutarlılık ilkelerine uymuyor.

Ozanyan'ın daha sonraki faaliyetleri ile ilgili bilgi vermek üzere, Ermeni Ulusal Bilimler Akademisi Tarih Enstitüsü Araştırmacısı Suren T. Sargsyan'ın satırlarına bakalım. “...1915 Nisan ayında zor bir durumda Andranik, alayının cesareti ve komuta kabiliyeti sayesinde Rus ordusu zafer kazanmıştı. Andranik'in hizmetlerini değerlendiren Rus Genelkurmay Başkanı, onu Başkomutanlık rütbesine getirdi." Osmanlı Devleti'nin Rusya'ya karşı savaştığı bir cephede, Ermeni komutan sayesinde Rusya'nın savaş kazanması ve o komutanın da rütbeyle onurlandırılması Andranik'in bir kahraman olarak değerlendirildiği platformda öznel bir bakış açısıyla yaklaşımda bulunulduğunu göstermektedir.

Osmanlı Devleti'nin son döneminde Ermeniler sadece Rus ordusunun içinde değil, İngiliz ve Fransız orduları içinde de yer almışlardır. Ermeniler bu ordulara verdikleri destek karşılığında bu ülkelerden büyük maddi destek almışlar ve silahlı faaliyetlerine devam etmişlerdir. (Sarkisyanz 1975.) Bu faaliyetlerin liderlerinden birisi de Andranik'tir. Andranik sadece Osmanlı Devleti sınırları içinde değil, Balkanlar, Kafkaslar ve Avrupa'da da siyasi faaliyetlerde bulunmuștur.

\section{Ermenilerin Gözüyle Andranik Ozanyan}

Aşağıdaki fotoğrafta, 10 Kasım 1921 tarihine ait, Stookie Allen tarafından hazırlandığı belirtilen ve ismi «New York Journal-American» olan derginin kapağı görülmektedir. Derginin kapağında Andranik'le ilgili övgü dolu sözler ve onu askeri üniforma ile gösteren karikatürler yer almaktadır. Bu sözlerden bazıları şu şekildedir: 0 , güçlüye karşı zayıfın yanında yer alan şampiyondur. Andranik, dünyanın gördüğ̈̈ en görkemli, en romanik en etkili kavga eden adamıdır.O, ülkesi yararına çalışırken öldü. Dergi kapağındaki cümleler Andranik'le ilgili olumlu sloganlar șeklinde altalta sıralanmış ve bu sloganlar Andranik karikatürleriyle tamamlanmıștır. 


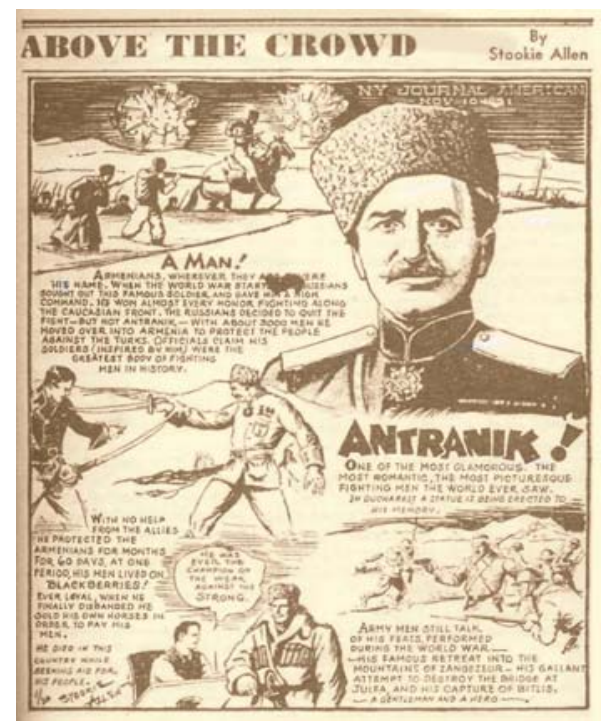

Ermeniler için Andranik Ozanyan'ın önemine dair bir başka örnek verecek olursak aşağıdaki resimlerde görülen anma parasını verebiliriz. Dolaşımsız madeni para olan bu anma parası $40 \mathrm{~mm}$ çapında ve Türk Lirası değeri olarak 7.63 TL değerinde bir paradır. Andranik'in 150. Doğum gününü anmak için bastırılan bu madeni paranın arka yüzünde Ermenistan Cumhuriyeti, 2015,1000 Dram yazmaktadır. Paranın ön yüzünde Andranik'e ait bir suret ve bir söz yazmaktadır. Bu suret, Paris'teki Père-Lachaise Mezarlığı'ndaki Andranik Anıtı'ndaki at sırtında Andranik heykelidir. Paranın üstünde, Andranikin doğum ve ölüm tarihleri olan 18651927 tarihleri yazmaktadır. Ayrıca, Andranik'e ait olan, “Halkımın özgürlüğü ve esenliği için savaştım" sözü de paranın ön yüzünde yer almaktadır. http://worldcoinnews.blogspot.com.tr/2015/03/ [04.11.2017, 23.20] Bu iki örnekte de dikkat çekici nokta şudur ki Andranik'in bir kahraman olarak ilan edilmesinde sadece Ermeniler değil Amerika, Avrupa devletleri ve Rusya da büyük rol oynamıştır.
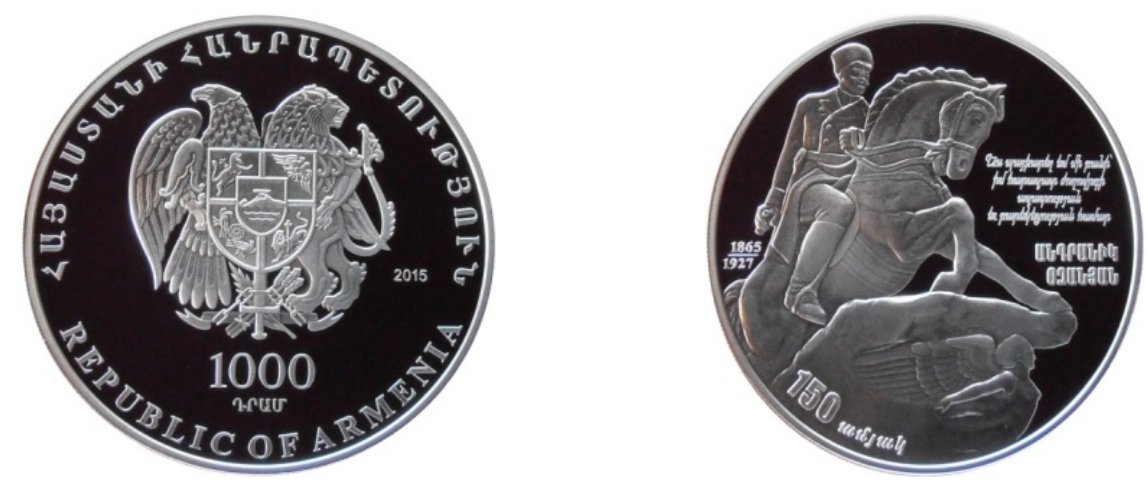

Andranik, Ermeniler için hem tarihi hem edebi bir kahramandır. Ermeni edebiyatı için kurgusal bir figür olan Andranik çeșitli şiirler, şarkılar ve hikâyelerde de kurgusal bir karakter olarak yer almaktadır. Örneğin, 1905 yılında Siamanto isimli bir şair Cenevre'de "Andranik" isimli bir şiir yazmıştır(Uhưưưpn / Siamanto 1905: 9). 1920 yılında, Vahan Totovents, General 
Andranik ve savaşlarıyla ilgili bir kitap yayınlamıştır.1936 yılında, Ermeni asıllı Amerikan yazar William Saroyan, Andranik ve Ermenistan hakkında kısa bir hikâye yazmıştır. Bir başka Ermeni asıllı Amerikalı yazar Hamasteğ, Andranik ve diğer fedilerle ilgili "Beyaz Atlı" isimli bir roman yazmıştır. Bu örnekler daha da arttırılabilir.

\section{Türklerin Gözüyle Andranik Ozanyan}

Osmanl, Rus ve Azerbaycan Arşivlerini kullanarak incelemelerde bulunan araştırmacıların verilerinden yararlanarak, Andranik Ozanyan'ın Osmanlı Devleti aleyhinde yürüttüğ̈ faaliyetlere örnekler verebiliriz. Andranik Ozanyan, 1901 yılı itibariyle Bitlis vilayetine bağlı Sasun ve Muş yörelerinde isyan teşebbüslerine başlamıştır. Yörenin dağlık ve ulaşımının zor olması Andranik'in ve diğer Ermeni komitacılarının burayı seçmesine sebep olmuştur. Bu bölgelerde, Ermenilerin katledildiği yönünde haberler çıkarılarak Avrupa'nın dikkatini çekmek isteyen Ermeni ileri gelenleri kargaşa çıkararak büyük güçlerin tekrar devreye girmesini sağlamıştır. Büyük güçlerin yardımıyla bölgede özerk bir Ermenistan kurmak amacıyla hareket eden Ermeniler, devletin kendilerini koruyamadığı düşüncesini yaymak istiyorlardı. Üzerlerine korku saldıkları halkın Ermenilere saldırması da bir başka beklentiydi Ermeni ihtilalciler için. Çünkü karşı tarafın saldırısının Ermenilerin saldırılarını haklı çıkaracağına inanıyorlardı. Andranik Ozanyan'ın da bu yörede gerçekleștirdiği eylemler, yöredeki kır köy yaşantısını sarsmaya yöneliktir. Böylece bu bölgedeki Müslümanları ve Ermenileri birbirlerine düşman yapan isyancılar bölgede bağımsız Ermenistan kurma yönünde bir adım daha atmış olmaktadır. (Sertçelik 2015: 232-235).

Andranik Ozanyan'ın 1904 Nisan ayında başlattığı isyan hareketi, Taşnak merkezinin isteği ile Sasun bölgesinde başlayan isyanda Osmanlı birliklerinin sayısı 10.000, Ermenilerin sayısı 1000 civarındadır. $\mathrm{Bu}$ isyandan sonra Antranik ve çetesi Muş civarındaki dağlara çekilmişlerdir. Bu arada Avrupa Devletleri'nin dikkatini çekme amacıyla da Muş ve etrafındaki Ermeni köylerini boşaltarak halkı Muş Ovası'na göndermişlerdir. (Selvi 2003: 465). Muş ve çevresinde 1904 yılının 20 Kasım'ında baş gösteren olayların yöneticisi olan Andranik, Talvorik Dağı'na tırmanarak Osmanlı birliklerine karşı direnmeye devam eder. Ancak, burada başarı elde edemeyince çetesiyle birlikte Van'a doğru yol almaya başlar. Andranik, sonrasında Kafkasya'ya geçer ve burada Osmanlı Devleti'ne karşı propaganda çalışmalarında bulunur. Birinci Dünya Savaşı döneminde yeniden güç toplayan Andranik oluşturulan Ermeni gönüllü birliklerine komuta ederek doğu vilayetlerinde olaylar çıkarmaya devam eder. (Sertçelik 2015: 232-235). Andranik'in yukarıdaki paragrafta bahsedilen faaliyetleri değerlendirildiğinde bir kahramandan çok bir çete reisi veya bir eylemci profilinin ortaya çıtığını görürüz.

“Osmanlı Devleti Birinci Dünya Savaşı'na girmek için hazırlıklara başlayıp seferberlik ilan edince, içeride hazırlıklarını tamamlayan komiteler, Kafkasya'daki gönüllü alaylarıyla Rus 
ordusunun öncü kuvvetleri olarak harekete geçtiler." (Selvi 2003: 465). Rus ordusu gönüllü toplama hareketi Tiflis'teki Ermeni Milli Bürosu'nun kararıyla 1914 yılının son aylarında başladı. Taşnaksütyun Komitesi uzun zamandan beri çetecilik yapan kişileri askeri göreve çağırdı. Andranik, Keri, Varta, Hamasb, Armen Garo göreve çağırılan çete reislerindendi (Selvi 2003: 465). Bu örneklerden de anlaşılacağı gibi Andranik Ozanyan Rus ordusu için hizmet etmiş ve Osmanlı Devleti'ne karşı büyük bir isyan ve çetecilik faaliyetlerine girişmiştir.

Azerbaycan Devlet Arşivleri'ndeki belgeleri inceleyen araştırmacıların verdiği bilgilere göre Andranik Ozanyan'ın bölgede giriştiği faaliyetler ve İngiliz güçlerinden yardım alarak yaptığı komite ve çetecilik çalışmaları görülmektedir (Mustafayev 2012: 279). Ermenilerin, Azerbaycan Türklerine karşı giriştiği saldırılar Bakü, Nahçıvan, Kuba, Gence, Karabağ ve Zengezur bölgelerini kapsamaktadır (Mustafayev 2012: 279).

Ermenilerin bağımsızlık hareketleri dediği faaliyetler Osmanlı Devleti'ne karşı kalkışılan isyan faaliyetleridir. Özellikle de Osmanlı Devleti'nin dış güçlerle savaşıyor olduğu dönemlerde ayrıca kendi içinden gelen isyanlar ve faaliyetler dolayısıyla da çok zor zamanlar geçirdiğini biliyoruz. $\mathrm{Bu}$ sebeple bu tür faaliyetler Osmanlı Devleti tarafından isyan olarak nitelendirilmektedir. Osmanlı Devleti'nin bölgede yaşayan büyük ve eski bir devlet olmasından dolayı kendi yönetimsel yapısında yaşayan bir etnik gruba ait hareketleri isyan olarak adlandırmasında eleştirel anlamda bakıldığında nesnellikle ilgili bir sorun olmadığı görülmektedir.

\section{Sonuç}

Ermeni, Rus ve Azeri kaynaklarından örnekler verilerek değerlendirilen Ermeni kaynaklarında ve Ermenilerde olayların değerlendirilmesi konusunda nesnellikten çok öznellik olduğu görülmektedir. Verilen örnekler, Ermeni kaynaklarının olayları objektif olarak değerlendirmekten uzak olduğunu göstermiştir. Tarihteki olayların, verilen bilginin doğruluğu, tutarlılığı, açıklığı gözetilmeden sadece Ermenilerin duygularına ve ihtiyaçlarına göre yorumlandığı görülmüştür. Andranik Ozanyan örneğinde ihtiyaç duyulan kahraman, kurtarıcı, lider kurgusunun yapıldığı açıktır. Tarihte kahramanlık ya da kahraman kavramının hangi niteliklerden beslenerek hak ettiği konuma yükseldiği önemlidir. Çünkü bu kavramların insanlık tarihinde ve tarih biliminde bıraktığı iz derin, üstlendiği rol büyüktür. Ermenilerin kahramanı Andranik Ozanyan'ı Carlyle'nin sorguladığı kahraman/kahramanlık yeterlikleri üzerinden sorgularsak onun dünya tarihine nasıl şekil verdiği ve hangi fikirleri üretip yaydığı soruları cevapsız kalır. Çünkü Ozanyan bu iki soruya da katkıda bulunabilecek fiziksel ve fikirsel bir katkıyla tarih sahnesinde rol almamıştır. Oysaki ne yaptığı ve insanları nasıl etkilediği sorularına verilebilecek yanıtlar ise oldukça açık ve nettir. Çünkü Ozanyan, Osmanlı'nın doğu vilayetlerinde gerçekleştirilen eylem ve isyanların birçoğuna liderlik etmiş; Balkanlarda ve Kafkaslarda 
gerçekleştirilen Osmanlı karşıtı isyan ve eylemlerde rol almış bir "Ermeni kahramanıdır". Osmanlı Devleti'nin doğudaki vilayetleri üzerinde bir Ermenistan Devleti kurmak amaciyla ayaklanmış, bu vaadler ve amaçlarla Osmanlı Devleti içinde yaşayan Hırıstiyan tebaayı isyanlara ve ayaklanmalara dâhil etmiştir. Onun Ermenilerce tarihi bir figür olarak değerlendirmesi sonucu ortaya çlkan bir "kahraman"; Türkler tarafından tarihi bir figür olarak değerlendirmesi sonucu ortaya çıkan bir "çete reisi” kimliği vardır. Andranik Ozanyan'ın yaşamı ve faaliyetleri nesnellik ve kahramanlık kriterleri üzerinden değerlendirildiğinde ise ortaya çıkan figür Ermenilerin gözünde canlandırdığı kahraman kurgusuyla örtüşmemektedir.

\section{KAYNAKLAR}

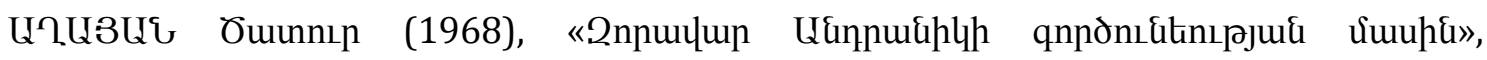

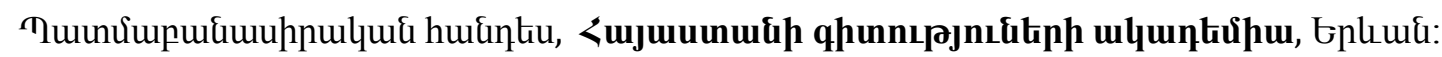

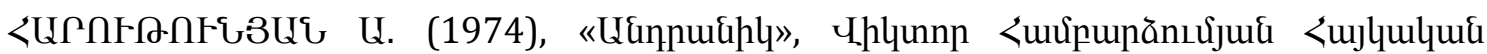

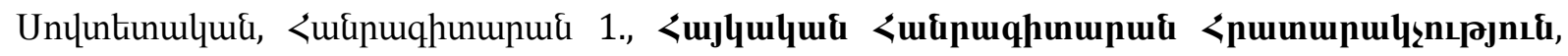
Enluma:

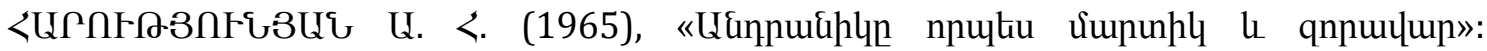

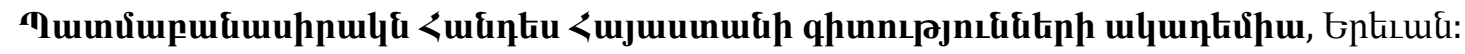

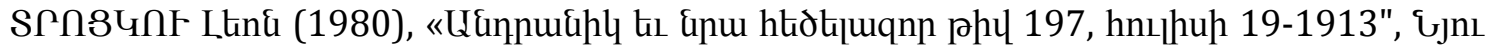
3npp: Uư์unu ưứnц:

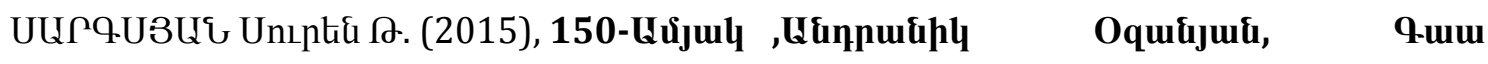

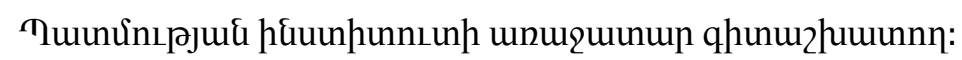

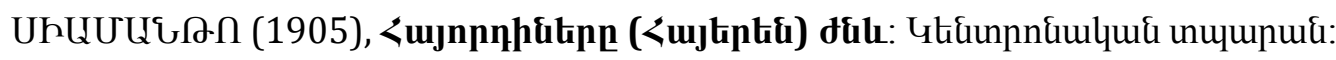

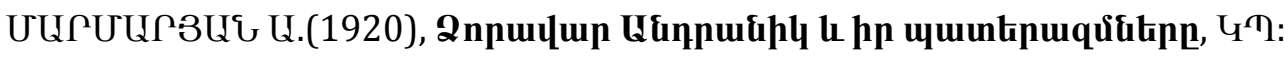

DASNABEDIAN Hratch (1989), History of the Armenian Revolutionary Federation Dashnaksution (1890-1924), Milan.

SARKiSYANZ Emanuel (1975), A Modern History of Transcaucasian Armenia. Social, Cultural and Political, Udyama Commercial Press.

WALLER Christopher J. (1990), In the Life of the Armenian Nation (Revised Chapter 2). New York. St. Martin.

SELVİ Haluk (2003), "Anadolu'dan Kafkasya'ya Bir Ermeni Çete Reisi: Antranik Ozanyan”, Sekizinci Askeri Tarih Semineri Bildirileri I, (24-26 Ekim 2001, İstanbul) 441-459.

SERTÇELIKK Seyit (2015), Rus ve Ermeni Kaynakları Işı̆̆ında Ermeni Sorunu:Ortaya Çıkış Süreci 1678-1914, SRT Yayınları, Ankara 2015. 
ERMENILLEIN TARİHİ OLAYLARA YAKLAŞIMINDAKİ NESNELLİĞİN SORGULANMASI:

“KAHRAMAN"ANDRANIK OZANYAN ÖRNEĞİ - Yrd. Doç. Dr. Melek SARI GÜVEN

MUSTAFAYEV Beşir (2012), “Nahçıvan Olayları ve General Andranik ozanyan'ın Nahçıvan'daki Katliamaı (Arşiv Belgelerinin İzinden)”, A.Ü. Türkiyat Araştırmaları Enstitüsü Dergisi, Sayı: 47, Erzurum, 277-301.

THOMAS Carlyle (1840), On Heroes, Hero-Worship and the Heroic in History, University of California Press, 1993.

Internet service: http://hyeforum.com/index.php?showtopic=18153 